\title{
ИССЛЕДОВАНИЕ РЕТИНОПРОТЕКТИВНОГО ДЕЙСТВИЯ СЕМАКСА
}

\author{
С.С. Луговской, С.С. Черняева, А.А. Пересыпкина
}

Кафедра фармакологии и клинической фармакологии, ФГАОУ ВО «Белгородский национальный исследовательский университет», 308015, Россия, Белгород, ул. Победы, 85.

DOI: 10.19163/MedChemRussia2021-2021-472

E-mail: anny_87_@mail.ru

На сегодняшний день важной задачей фармакологии является поиск специфических и эффективных средств для лечения гипертензивной нейроретинопатии, обладающих эндотелио- и нейропротекторной активностью [1], к которым можно отнести семакс [2]. Целью исследования явилось изучение влияния семакса на микроциркуляцию в сетчатке на модели гипертензивной нейроретинопатии у крыс.

В эксперимент вошли группы: 1) контроль ( $\mathrm{n}=10) ; 2$ ) с моделью гипертензивной нейроретинопатии [3] (n= 10); 3) с коррекцией патологии семаксом в дозе 7,2 мкг/100 г массы крысы $(n=10)$; 4) с коррекцией пикамилоном в дозе 3 мг/100 г (n = 10). Раствор назальных капель семакс вводили в полость носа ежедневно с 22-го по 28-й день эксперимента. Введение пикамилона в дозе 3 мг/100 г в/ж проводили за 60 минут до введения L-NAME, с 22-го по 28-й день эксперимента. Перфузию сетчатки у крыс измеряли на 29-е сутки методом лазерной доплеровской флоуметрии (ЛДФ).

В группе с моделированием патологии перфузия снизилась на 44,3\% $(p<0,05)$ по сравнению с контролем. При коррекции семаксом уровень перфузии достоверно отличался (на 9,4\%, p<0,05) от среднего значения контрольной группы, увеличился на 62,7\% (p<0,05) по сравнению с группой с моделью и достоверно отличался (на 9,9\%, p<0,05) от среднего значения группы с пикамилоном в дозе 3 мг/100 г. При коррекции пикамилоном уровень микроциркуляции в сетчатке достоверно отличался (на 17,6\%, p<0,05) от среднего значения контрольной группы, увеличился на 48,0\% ( $<<0,05)$ по сравнению с группой с моделью.

Предположительно, улучшение микроциркуляции в сетчатке при воздействии семакса при коррекции гипертензивных изменений сетчатки у крыс может быть связано с наличием у семакса антиоксидантных и эндотелиопротекторных эффектов.

\section{Литература}

[1] А.А. Пересыпкина, М.В. Покровский, В.О. Губарева, Е.А. Левкова, Кубанский научный медицинский вестник. 2018, 25(1), 103-107.

[2] А.А. Елагина, Ю.Д. Ляшев, Е.Б. Артюшкова, А.Ю. Ляшев, Т.В. Проняева, А.Р. Шехине, Экспериментальная и клиническая фармакология. 2020, 83(11), 12-15.

[3] A.A. Peresypkina, A.L. Pazhinsky, A.S. Pobeda, A.A. Dolzhikov, N.I. Zhernakova, O.A. Osipova, A.P. Grigorenko, V.A. Ruzhenkov, Indo American journal of pharmaceutical sciences. 2017, 4(10), 3695-3700. 